\title{
TEMPAT PENGOLAHAN SAMPAH TERPADU DENGAN MENGGUNAKAN SISTEM EATAD (Enhanched Autogenous Thermopilic Aerobic Digestion)
}

\author{
Humairoh, Daryati, Amos Neolaka
}

\begin{abstract}
Abstrak
Sistem EATAD merupakan sistem pengolahan sampah yang dapat mengolah bahan baku sampah organik sebesar $300 \mathrm{~m} 3 /$ hari dicampur dengan material kertas sebanyak $75 \mathrm{~m} 3 /$ hari yang dilumat, lalu dicerna dan diurai menjadi produk pupuk IBR Solid dan IBR Liquid oleh bakteri Lactobacillus Bulgaricus dan Streptococcus Thermophyllus. Pengolahan selama 5 hari, dengan dimensi pengolahan terdiri dari : bak penampung (16,5 $m \times 5,5 m \times 4 \mathrm{~m})$, Hummer Mill, Electromagnetic Shearator, Air Shearator, bak penampung II (16,5 m x 5,5 m x $3 \mathrm{~m}), 25$ buah Digester Tank kapasitas $27,21 \mathrm{~m}^{3}$, Filter Press, oven, mesin penggiling, bak pengendap (12 $\left.\mathrm{m} \times 4 \mathrm{~m} \times 3 \mathrm{~m}\right)$, tangki pemurnian (12 $m \times 4 m \times 3 m$ ), dan mesin pengemas produk.

Selama ini pupuk hasil pengolahan lain tidak memiliki standar mutu, sedangkan sistem EATAD ini menghasilkan produk pupuk yang memiliki standard mutu, sehingga perencanaan menyimpulkan bahwa pengolahan sampah dengan sistem EATAD dapat dilaksanakan
\end{abstract}

Kata Kunci: pengolahan sampah

\section{PENDAHULUAN}

Dengan berakhirnya masa kontrak Tempat Pengolahan Sampah Terpadu (TPST) Bantar Gebang - Bekasi yang memiliki luas \pm 110 ha dengan daya tampung $\pm 14.000 \mathrm{~m}^{3}$ dan jumlah sampah yang masuk sebesar $\pm 20.153 \mathrm{~m} 3 /$ hari (termasuk pemda Bekasi 700 m³hari),[ Dinas Kebersihan Propinsi DKI Jakarta,2002, h. 29] menimbulkan permasalah baru, karena selama ini DKI Jakarta menampung 80 \% timbulan sampahnya di TPST tersebut.

Jumlah penduduk DKI Jakarta saat ini mencapai $+7,46$ juta jiwa[Badan Pusat Statistik Propinsi DKI Jakarta, 2003, h. 60.], menghasilkan volume sampah sebesar + 25.176 m3/hari [Badan Pusat Statistik Propinsi DKI Jakarta, 2003, h. 67]. jika tidak segera

$\begin{array}{lcr}\text { Humairoh } & \text { Dra, Daryati,MT } & \text { DR Amos Neolaka MPd } \\ \begin{array}{l}\text { Alumni Jurusan Teknik Sipil } \\ \text { Fakultas Teknik }\end{array} & \text { Staf Pengajar Jurusan Teknik Sipil } & \text { Staf Pengajar Jurusan Teknik Sipil } \\ \text { Universitas Negeri Jakarta, 13220 } & \text { Fakultas Teknik } & \text { Fakultas Teknik } \\ & \text { Universitas Negeri Jakarta, 13220 } & \text { Universitas Negeri Jakarta, 13220 }\end{array}$


dimusnahkan atau diolah, dalam hitungan hari, DKI Jakarta bisa berubah menjadi kota sampah.

Mengingat banyaknya dampak negatif yang diakibatkan oleh sampah akibat penerapan sistem dan manajemen pengolahan yang kurang tepat di lokasi TPST Bantar Gebang - Bekasi, yaitu penerapan pengolahan sampah sistem Sanitary Landfill yang tidak ramah lingkungan dan tidak ekonomis, sehingga tidak direkomendasikan lagi, dan diganti dengan pengolahan sampah sistem EATAD.

Komponen fisik sampah dikelompokkan menjadi dua jenis, yaitu sampah organik atau disebut juga sampah yang mudah membusuk, terdiri atas zat-zat organik seperti sisa sayuran, sisa daging, daun, tulang, dan lainnya, dan sampah non organik, yaitu komponen fisik sampah yang tidak membusuk, seperti plastik, karet, kertas, logam, bahan bangunan bekas, dan lain-lain.

Sampah di Indonesia merupakan sampah dengan karakteristik yang berbeda-beda atau masih tercampur antara sampah organik dan sampah non organik, sehingga perlu dilakukan proses pemilahan terlebih dahulu karena sistem EATAD hanya mengolah bahan baku berupa sampah organik dicampur $20 \%$ material kertas, yang kemudian diolah oleh serangkaian pengolahan sampah yang dapat disesuaikan dengan yang telah ada di Indonesia kecuali Shearator yang memiliki hak paten, namun dapat diganti dengan produk lain yang sejenis, sehingga diperoleh produk akhir berupa pupuk padat dan pupuk cair yang diberi nama IBR Solid dan IBR Liquid.

Kedua pupuk tersebut telah mengalami proses pengujian di laboratorium Vancouver - Canada, dan dinyatakan terbukti mampu menghasilkan pupuk organik yang bersih dan berkualitas tinggi serta memiliki standard mutu yang tetap, dan dapat dijadikan profit center.

Melihat berbagai kelebihan dari sistem EATAD, ditambah lagi sistem ini ramah lingkungan, membuat sistem ini dianggap cocok untuk diterapkan di Indonesia yang padat penduduk.

Dari uraian di atas, maka diidentifikasikan beberapa masalah, yaitu : Bagaimanakah perencanaan Tempat Pengolahan Sampah Terpadu (TPST) dengan sistem EATAD ? Apakah sistem EATAD ini lebih ekonomis ? Bagaimana standard mutu pupuknya ? Apakah sistem EATAD bisa dijadikan suatu usaha yang Profit Center ? Bagaimana dampak penerapan sistem EATAD terhadap lingkungan ?. 
Karena cakupan masalah yang dihadapi sangat luas sekali, sehingga pembahasan dibatasi hanya pada perencanaan Tempat Pengolahan Sampah Terpadu dengan sistem EATAD (Enhanced Autogenous Thermopilic Aerobic Digestion) dengan bahan baku sampah organik yang telah mengalami proses pemilahan.

\section{METODOLOGI}

Tujuan perencanaan untuk mendapatkan desain yang berupa volume dan dimensi tempat pengolahan sampah dengan sistem EATAD dan untuk mendapat rancangan struktur yang dapat mengurangi permasalahan lingkungan yang diakibatkan oleh sampah. Waktu perencanaan pada semester ganjil tahun 2004/2005.

Perencanaan dilakukan dengan metode pengumpulan data dan penyusunan teoretis, serta studi kepustakaan sehingga didapatkan pedoman Perencanaan Tempat Pengolahan Sampah.

Teknik pengumpulan data dengan menggunakan format / pedoman observasi yang menulis data yang dibutuhkan dari badan atau instansi yang terkait. Dari Badan Pusat Statistik DKI Jakarta, diperoleh data DKI Jakarta, dari Dinas Kebersihan Propinsi DKI Jakarta diperoleh data jumlah timbulan sampah, data lokasi, dan data teknologi EATAD, dari internet diperoleh data EATAD, dan dari Studi Pustaka diperoleh data EATAD dan data penyusunan teoretis.

\section{HASIL DAN PEMBAHASAN}

Dinas Pekerjaan Umum mendefinisikan perencanaan merupakan pengetrapan caracara perhitungan atau percobaan yang dilakukan secara rasional, serta sesuai dengan prinsip-prinsip yang berlaku. [Dinas Pekerjaan Umum, 1991, h. 4.]

Sedangkan menurut Maudy, perencanaan adalah suatu proses mengembangkan tujuan perusahaan dan memilih kegiatan-kegiatan yang akan dilakukan di masa mendatang untuk mencapai tujuan tersebut. Hal ini mencakup :[ Maudy Warauw Purwatiningsih, h. 3.]

a. Memilih tindakan untuk mencapai tujuan tersebut. 
b. Menentukan langkah-langkah untuk menerjemahkan rencana menjadi kegiatan yang sebenarnya.

c. Melakukan perencanaan ulang guna memperbaiki kekurangan yang ada.

Data perencanaan yang diperlukan adalah jumlah timbulan sampah yang dihasilkan oleh penduduk DKI Jakarta perhari dan kapasitas pengolah.

\section{Tempat Pengolahan Sampah Terpadu}

Tempat Pengolahan Sampah Terpadu adalah tempat dimana sampah diisolasikan secara aman agar tidak menimbulkan pencemaran terhadap lingkungan sekitarnya, melalui penyediaan fasilitas dan perlakuan yang benar agar keamanan tempat dan lingkungannya dapat dicapai dengan baik [SNI 19 - 2454 - 2002, , h. 9.]

Sampah menurut Juli merupakan segala sesuatu yang tidak lagi dikehendaki oleh yang punya dan bersifat padat. Sampah ini ada yang mudah membusuk dan adapula yang tidak membusuk. Yang mudah membusuk terutama terdiri atas zat-zat organik seperti sisa sayuran, sisa daging, daun, dan lain-lain. Sedangkan yang tidak membusuk dapat berupa plastik, kertas, karet, logam, bahan bangunan bekas, dan lain-lain [Juli Somirat Slamet, 1994, h. 152.]

\section{Tabel 1 : Timbulan dan Sampah Terangkut Rata-rata Perhari Tahun 2002}

\begin{tabular}{|l|r|r|r|}
\hline \multicolumn{1}{|c|}{ Kotamadya } & $\begin{array}{r}\text { Timbulan Sampah } \\
\left(\mathrm{m}^{3} / \text { hari }\right)\end{array}$ & $\begin{array}{r}\text { Terangkut } \\
\left(\mathrm{m}^{3} / \mathrm{hari}\right)\end{array}$ & Sisa (m³/hari) \\
\hline Jakarta Utara & 4.709 & 4.571 & 322 \\
\hline Jakarta Timur & 4.702 & 4.380 & 441 \\
\hline Jakarta Selatan & 5.279 & 4.838 & 318 \\
\hline Jakarta Barat & 5.001 & 4.683 & 531 \\
\hline Jakarta Pusat & 5.485 & 4.954 & 1.014 \\
\hline Kep. Seribu & & 736 & \\
\hline Jumlah & 25.176 & 24.162 & \\
\hline
\end{tabular}

Sumber : Dinas Kebersihan Propinsi DKI Jakarta, Informasi Pengelolaan Kebersihan Tahun 2002 (Jakarta: DK, 2004), h. 3.

Timbulan sampah merupakan banyaknya sampah yang dihasilkan perorang perhari dalam satuan volume maupun berat. [Juli Somirat Slamet, 1994, h. 2.] 


\section{Sistem EATAD}

EATAD atau singkatan dari Enhanced Autogenous Thermopilic Aerobic Digestion, merupakan proses pencernaan alamiah dengan menggunakan Mikroba Aerobik yang dikondisikan pada suhu tertentu.

Dengan kata lain, EATAD merupakan suatu aplikasi perkembangan ilmu bioteknologi dalam dunia industri. Sebuah teknologi yang menggunakan mikrobiologi dalam proses pengolahannya. Mikrobiologi adalah suatu ilmu yang mempelajari kehidupan makhluk yang bersifat mikroskopik yang disebut mikroorganisme atau jasad renik. [Srikandi Dardiaz, 1992, h. 15]

Jasad renik yang berperan dalam pengolahan ini adalah bakteri Lactobacillus Bulgaricus dan Streptococcus Thermophyllus. Bibit ini dapat diperoleh di Puslitbang Peternakan di Bogor.

Sistem EATAD akan melalui beberapa tahapan yang diambil dari proses pengolahan sampah menjadi pelet. Lihat gambar di bawah ini : [Yul H. Bahar, 1985, h. 53.]

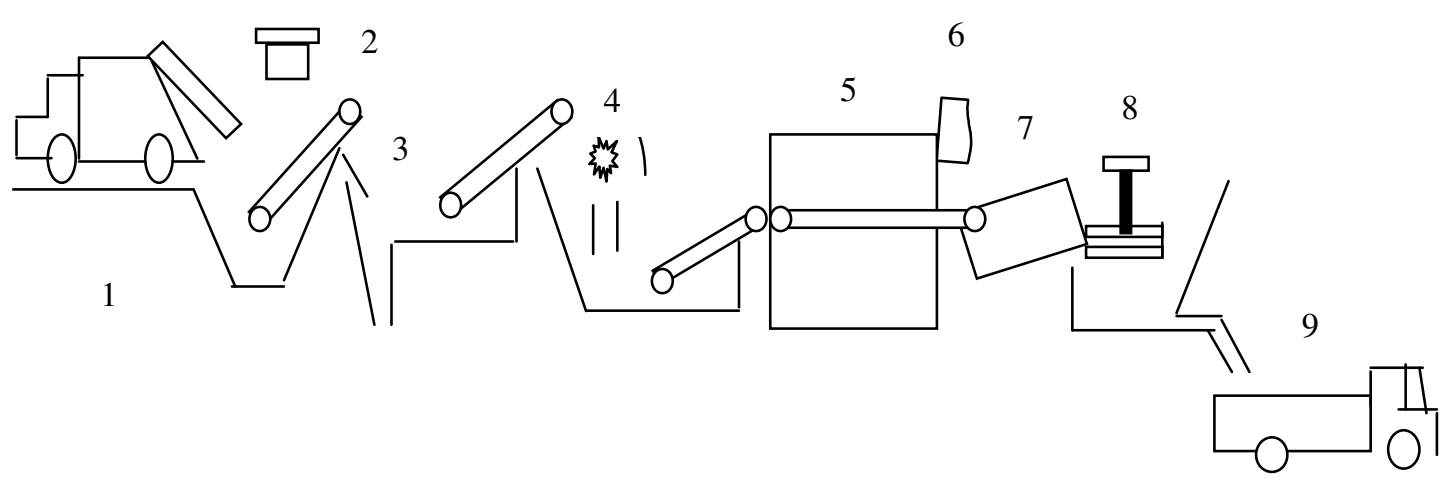

Keterangan Gambar :

1. Pembongkaran Sampah dari Truck, 2. Electromagnetic Separator, 3. Air Separator, 4. Knive Mill, 5. Tunnel Dryer, 6. Tempat Bahan Perekat, 7. Silinder Pengaduk, 8. Mesin Pelletizer, 9. Pelet Sampah Siap Didistribusi. 


\section{Tahap pengolahan sistem EATAD :}

\section{Tahap Pemilahan Sampah 1}

Sampah di Indonesia dibagi menjadi 2 jenis, yaitu sampah organik dan sampah non organik. Sampah berdasarkan sifatnya terdiri dari sampah yang mudah membusuk dan yang tidak mudah membusuk, sampah yang mudah terbakar, dan sampah yang tidak mudah terbakar.

Seperti yang telah kita semua ketahui bahwa sampah di Indonesia masih bercampur, sehingga dapat menyulitkan dalam proses pengolahannya, sehingga perlu di buat unit pemilah sampah tersendiri.

Disamping itu, sampah di Indonesia masih tercampur antara yang berdimensi sangat besar, besar, sedang, dan kecil, sehingga pemilahan sampah dilakukan sebanyak 2 kali. Pada tahapan I ini, sampah yang dipilah adalah komponen komposisi sampah berdimensi besar dan sedang seperti yang tersebut pada tabel di bawah ini, dengan menggunakan tenaga manusia. Sedangkan pada tahapan II, sampah yang dipilah adalah sampah berdimensi kecil yang masih tersisa dari proses pemilahan tahap I.

Komponen komposisi sampah adalah komponen fisik sampah seperti sisa makanan, kertas-karton, kayu, kain-tekstil, karet-kulit, plastik, logam besi-non besi, kaca, dan lain-lain (misalnya tanah, pasir, batu, keramik, dan sebagainya). [Dinas Kebersihan Propinsi DKI Jakarta, 2003, h. 18.] Sedangkan komponen komposisi sampah organik di Indonesia sebesar $65,05 \%$

\section{Tahap Pemilahan Sampah II}

Setelah sampah berdimensi besar terpilah, maka sampah berukuran kecil dipilah kembali dengan menggunakan mesin. Di Eropa, ada perusahaan yang mengoperasikan mobil pengangkut sampah yang dapat memilah atau mensortasi sampah menurut jenisnya disamping dapat menghancurkan dan memadatkan sampah (compactor and sortation truck).

Pada mobil ini, sampah yang masuk dipilah menurut jenisnya, metal dipisahkan dengan magnetic separator, bahan dari kaca dan bahan berat lainnya dipisahkan dengan 
air separator, setelah dipisahkan ditampung pada ruangan khusus dalam mobil tersebut. Sedangkan sampah jenis lainnya dihancurkan (grinding) dan dipadatkan.

Pada sistem ini, sampah dimasukkan ke dalam bak penampung, dengan conveyor dibawa ke mesin penghancur (tollemacemache pulvezer) yang dapat menghancurkan sampah menjadi bagian yang kecil-kecil, sekaligus dipisahkan dari kaca dan benda berat lainnya.

Sampah yang telah dihancurkan, dengan conveyor dibawa ke mesin pemisah metal dengan sistem magnet (magnetic separator). Lalu rollafin separator, memisahkan sampah plastik, kain, kertas dan jenis lainnya.

Salah satu sistem pemilahan sampah yang telah dipakai adalah sistem ROLLAFIN, lihat gambar dibawah ini. [Yul H. Bahar, 1985, h. 14]

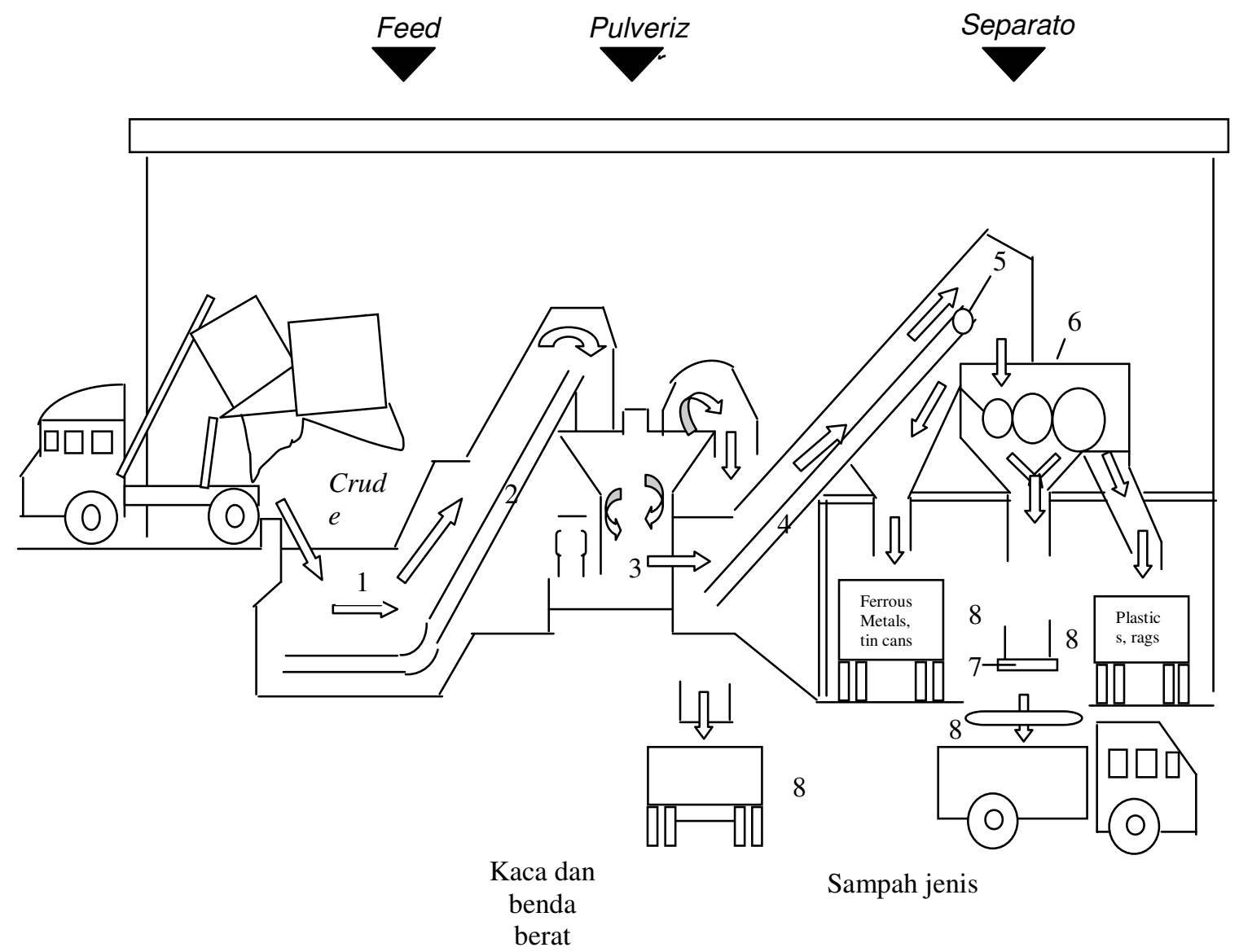

Keterangan Gambar : 1. Tempat Penampungan Sampah, 2, 4, 5, \& 7. Conveyor, 3. Mesin Penghancur Sampah "Tollemache Pulverizer", 6. Rollafin Separator, 8.Kendaraan Pengangkut. 
Sampah yang telah dipilah akan memasuki saluran khusus dan langsung di tampung, lalu dibawa ke perusahaan pengolah sampah. Sampah organik ke tempat pengolah dengan sistem EATAD, sampah non organik ke tempat daur ulang atau ke tempat pengolah sistem Incinerator. Sebelum dibawa, sampah dapat pula dilakukan pemadatan (compacting) dan pembungkusan (balling) terlebih dahulu sehingga lebih memudahkan transportasinya.

Jika tahapan pemilahan sampah ini dilakukan di Indonesia, maka proses pengolahan sampah dengan sistem-sistem lain akan menjadi lebih mudah, sehingga menarik investor dari dalam maupun luar negeri. Bahan baku yang dibawa ke Tempat Pengolahan adalah sampah organik yang telah melalui tahapan pemilahan seperti tersebut di atas, jadi di TPST tidak lagi dibuat unit pemilahan.

\section{Penimbangan Muatan Sampah (Weighting)}

Setelah sampah datang ke lokasi pengolahan, lalu ditimbang dengan tujuan untuk mengetahui jumlah yang sudah masuk ke dalam lokasi Pengolahan. Sampah yang di timbang adalah sampah organik sebesar 300 ton, dengan biaya Tipping Fee sebesar Rp. 52.500/ton, sehingga biaya yang dikeluarkan Dinas Kebersihan Propinsi DKI Jakarta dan jumlah uang yang diterima oleh jasa pengolah sebesar Rp. 15.750.000. Hasil perhitungan data penimbangan hanya menunjukkan berat sesungguhnya.

\section{Penurunan Muatan Sampah ( Tipping)}

Sampah organik yang telah di timbang diturunkan ke dalam bak penampung.

\section{Bak Penampung}

Bak penampung berbentuk empat persegi panjang dengan perbandingan $P: L=$ 1 : 3. Sampah organik yang telah terkumpul di bak penampung diangkat oleh Conveyor Belt bersekat-sekat.

Conveyor Belt ini diganti dengan alat pengangkut lain, dalam hal ini dipilih Crane, dengan melihat dari proses pengolahan pelet sampah sebagai suplemen bahan bakar batubara pada perusahaan listrik tenaga uap di Perancis [Yul H. Bahar, 1985, h. 57]. 
Penggantian Conveyor dengan Crane disebabkan karena khawatir dalam waktu beberapa hari saja Conveyor akan berhenti beroperasi karena penumpukan sampah yang tumpah di lubang sekatnya.

\section{Primary Digester}

Crane membawa sampah dan dimasukkan ke Hummer Mill, lalu Electromagnetic Separator bekerja mengangkat sampah jenis metal dan memisahkan sampah jenis plastik dengan menggunakan panas, lalu Air Separator memisahkan benda berat lainnya dengan hembusan angin.

\section{Mesin Grinding}

Sampah dibawa Conveyor Belt ke mesin grinding, yaitu mesin yang berfungsi untuk memperkecil dan menyeragamkan ukuran sampah. Cara kerja mesin ini yaitu, sampah organik dan $20 \%$ material kertas Koran atau sebanyak $75 \mathrm{~m}^{3} /$ hari dilewatkan pada roda gigi yang mempunyai pisau-pisau pemotong dan berputar dengan arah berlawanan, kemudian sampah di potong oleh roda gigi menjadi ukuran yang lebih kecil. Perlu diingat, pisau-pisau pada mesin ini harus cukup tajam sehingga proses pemotongan dapat dilakukan dengan sempurna.

Mesin Grinding dapat diganti dengan mesin Hummer Mill karena mesin ini dapat melumat sampah organik, sedangkan mesin Grinding hanya dapat memotong sampah menjadi ukuran kecil-kecil. Mengingat material kertas Koran mudah ditemukan dengan harga yang relatif murah, sehingga material kertas yang ditambahkan adalah material kertas koran yang memiliki ketebalan maksimal $1 \mathrm{~mm}$, dan daya serap terhadap air sebesar $45-55 \mathrm{~g} / \mathrm{m}^{2}$.

\section{Bak Penampung II}

Setelah sampah organik dan 20\% material kertas di lumat di Hummer Mill, kemudian dimasukkan ke dalam bak penampung II, lalu sampah diaduk oleh Crane hingga sampah organik dan material kertas koran tercampur rata. 
Banyaknya volume lumpur sampah $(\mathrm{Vt})$, yaitu = Volume sampah $(\mathrm{Vs})+$ Volume kertas koran (Vk). Sedangkan sampah yang terpilah, yaitu sampah jenis metal dan plastik, masuk ke saluran khusus sampah terpilah.

Tabel 2 : Komposisi Larutan Bahan Baku

\begin{tabular}{|l|c|}
\hline \multicolumn{1}{|c|}{ Parameter } & Kandungan \\
\hline $\mathrm{PH}$ & 7,0 \\
\hline Total solid $(\%)$ & 5,8 \\
\hline Total volatile solid $(\%)$ & 3,6 \\
\hline Liquid & 94,2 \\
\hline BOD5 $(\mathrm{g} \text { atau } \mathrm{Kg})^{*}$ & 344,0 \\
\hline $\mathrm{COD}(\mathrm{g} \text { atau } \mathrm{Kg})^{*}$ & 711,0 \\
\hline TKN $(\mathrm{g}$ atau Kg) & 21,0 \\
\hline $\mathrm{NH} 3(\mathrm{~g} \mathrm{~N} \text { atau } \mathrm{Kg})^{*}$ & 5,5 \\
\hline Total $\mathrm{P}(\mathrm{g} \mathrm{P} \text { atau } \mathrm{Kg})^{*}$ & 2,5 \\
\hline Ortho $\mathrm{P}(\mathrm{g} \mathrm{P} \text { atau } \mathrm{Kg})^{*}$ & 2,0 \\
\hline Total $\mathrm{K}(\mathrm{g} \mathrm{K} \text { atau } \mathrm{Kg})^{*}$ & 8,8 \\
\hline
\end{tabular}

* Di ukur pada berat kering

Sumber : e - Solusi. Com., P.T. Biotama Recovery Indonesia (Internet, 2001), h. 4.

\section{Digester Tank}

Bahan baku sampah yang telah tercampur dimasukkan ke DigesterTank atau sampah mengalami Reject Digester, lalu terjadi proses pengolahan secara biologis di dalamnya.

Digester Tank dilengkapi dengan berbagai alat pengatur yang dapat menciptakan lingkungan yang optimal bagi pertumbuhan bakteri pengurai. Tingkat keasaman sampah diatur sehingga mencapai kadar $\mathrm{PH}$ seimbang \pm 7. Tekanan diatur sebesar $1 \mathrm{~atm}$, dan lain-lain. 
Tabel 3 : Kisaran Suhu untuk Pertumbuhan Jasad Renik

\begin{tabular}{|c|r|c|c|}
\hline Grup Jasad Renik & \multicolumn{3}{|c|}{ Suhu Pertumbuhan (\%) } \\
\cline { 2 - 4 } & Minimum & Optimum & Maksimum \\
\hline Psikrofil & $5-10$ & $10-15$ & $15-20$ \\
\hline Mesofil & $10-20$ & $20-40$ & $40-45$ \\
\hline Thermofil & $25-45$ & $45-60$ & $60-80$ \\
\hline
\end{tabular}

Sumber : Sugiharto, Dasar-dasar Pengolahan Air Limbah (Jakarta: Universitas Indonesia Press, 1987), h. 101.

Pada proses ini mikroba Thermopilic ditambahkan ke dalam bubur sampah. Tujuan pemasukan mikroorganisme ini adalah untuk menguraikan bahan organik, dan mempercepat proses pengolahan. Setelah itu temperatur bahan baku dinaikkan pada suhu optimum yaitu suhu antara $45-60{ }^{\circ} \mathrm{C}$. Suhu tersebut merupakan kondisi yang tepat bagi mikroba untuk berkembang biak.

Mikrobiologi adalah suatu ilmu yang mempelajari kehidupan makhluk yang bersifat mikroskopik yang disebut organisme/jasad renik.[Srikandi Fardiaz, 1992, h. 15.] Lactobacillus Bulgaricus masuk ke famili Lactobacillaceae jenis Lactobacillus, sedangkan Streptococcus masuk ke famili Streptococcaceae jenis Streptococcus. Keduanya masuk ke dalam kelompok bakteri Basili dan koki gram.[ Srikandi Fardiaz, 1992, h. 15.] Kelompok ini memiliki sifat sebagai berikut :[ Srikandi Fardiaz, 1992, h. 164-167]

1) Bersifat aerobik, umumnya cepat tumbuh pada makanan, dan berbentuk batang.

2) Memproduksi senyawa-senyawa yang menimbulkan bau busuk . Kelompok ini merupakan bakteri pembentuk gas, karena dapat mengoksidasi asam amino secara lengkap menjadi $\mathrm{CO}_{2}$ dan $\mathrm{H}_{2} \mathrm{O}$ dengan membebaskan amino atau kadang-kadang $\mathrm{H}_{2} \mathrm{~S}$ jika aminonya mengandung group sulfhidril.

3) Dapat tumbuh pada medium sederhana yang hanya terdiri dari mineral penting, amonia, dan karbohidrat atau asetat sebagai sumber karbon.

4) Merupakan bakteri Thermopilic yang tumbuh baik pada suhu optimum.

5) Dapat menggunakan senyawa sumber nitrogen sederhana.

6) Dapat mensintesis faktor pertumbuhan dan vitamin, dan membentuk pigmen.

7) Bersifat proteolitik (memecah protein) dan lipolitik (memecah lemak) atau petinolitik (memecah pectin), serta bersifat oksidase positif. 
8) Pertumbuhan pada kondisi aerobik.berjalan cepat dan biasanya membentuk lendir.

9) Karena produksi asam berjalan sangat cepat, maka pertumbuhan mikroba lain yang tidak diinginkan dapat terhambat.

10) Memberikan keuntungan karena pertumbuhannya lebih cepat dengan waktu generasi rata-rata kurang dari 1 jam, sekitar 20 menit sampai 1 jam.

Kesatuan peralatan yang digunakan untuk proses aerasi ini atau yang merupakan aspek vital dari teknologi EATAD adalah sebuah inovasi dalam rekayasa teknik yang disebut Shearator, yaitu peralatan aerasi yang dipatenkan dan khusus dikembangkan untuk meningkatkan efisiensi pencampuran udara ke dalam bubur sampah selama proses EATAD berlangsung[WWW.Google.Com., Shearator ( Internet, 2005), h. 1.]. Tanpa Shearator, sistem EATAD tidak mungkin dapat dioperasikan dalam skala komersial.

Namun dapat diganti dengan alat sejenis, dengan mutu dari hasil akhir berupa produk pupuk belum diketahui, sehingga perlu dilakukan uji laboratorium ulang.

Teknologi pengolahan sampah secara aerobik mengurangi produksi gas metan hingga $75 \%$, sehingga nutrisi alami dapat dipertahankan dan dapat mengurangi resiko timbulnya bau dan tekanan terhadap pupuk jika terkena panas.[ Fardiaz, op.cit., h. 113.]. Banyaknya udara yang diberikan tiap $\mathrm{m}^{3}$ lumpur sampah yaitu sebanyak $8-10 \mathrm{~m}^{3}$.[ Fardiaz, op.cit., h. 118].

Di dalam Digester Tank dipasang serangkaian alat pengatur suhu, $\mathrm{PH}$, oksigen yang terlarut, tekanan, dan lain-lain sehingga diperoleh larutan bahan baku dan lingkungan pertumbuhan mikroba pengolahan yang tepat, didalamnyapun berlangsung fase pertumbuhan logaritmik yang menghasilkan panas sehingga suhu medium meningkat dari suhu $45{ }^{\circ} \mathrm{C}$ menjadi $92{ }^{\circ} \mathrm{C}$. Secara otomatis, fase pertumbuhan memasuki fase pertumbuhan lambat, fase pertumbuhan tetap, fase menuju kematian, dan akhirnya memasuki fase kematian.

Suhu $92^{\circ} \mathrm{C}$ melebihi suhu pertumbuhan maksimal yang hanya sampai $80{ }^{\circ} \mathrm{C}$, sehingga mikroba pengolah menjadi mati, namun masih ada patogen yang tahan terhadap suhu ini. Sehingga bahan baku kemudian disterilkan terlebih dahulu pada suhu $12{ }^{\circ} \mathrm{C}$ selama 10 menit. Selama proses berlangsung, bahan baku diaduk terus menerus secara mekanis, kemudian didinginkan. 


\section{Filter Press}

Filter press adalah saringan bertekanan yang menghasilkan padatan dan cairan Lumpur.[ Sugiharto, Dasar-dasar Pengolahan Air Limbah (Jakarta : UI - Press, 1987), h. 141.] Pelat ditekan dengan tekanan sebesar 60 - $226 \mathrm{lb} /$ inci $^{2}$ dan dibiarkan selama 1 - 3 jam. Selama dalam proses penekanan, sedikit demi sedikit air akan keluar dari pelat dan jatuh ke tangki penampungan, sehingga dengan diambilnya air, maka Lumpur menjadi tidak berbau dan tidak mudah busuk. Banyaknya Lumpur yang dihasilkan ketebalannya bervariasi antara 2,5-3,8 cm dengan kadar air bervariasi antara $55-70 \%$.[ Sugiharto, Dasar-dasar Pengolahan Air Limbah (Jakarta : UI - Press, 1987), h. 142.]

\section{Oven}

Setelah bahan baku menghasilkan calon pupuk padatan dan cairan, lalu calon pupuk padatanpun dibersihkan dan dikeringkan dalam oven bersuhu $160-180{ }^{\circ} \mathrm{C}$ selama 1,5 - 2 jam atau diganti dengan pengering lainnya seperti Tunnel Drying yang dalam proses pengeringannya menggunakan panas buatan. Sampahpun berubah menjadi pelet kering.

\section{Mesin Penggiling}

Karena produk akhir yang diinginkan adalah pupuk organik berbentuk serbuk, maka pupuk padat yang telah kering, di giling hingga berubah menjadi bentuk serbuk.

\section{Bak Pengendapan}

Cairan pupuk hasil pengepresan Filter Press di tampung di dalam bak, kemudian diendapkan.

\section{Tangki Pemurnian}

Calon pupuk cair di proses untuk pemurnian dan konsentrasi dengan cara dipanaskan pada suhu $121^{\circ} \mathrm{C}$ selama 30 menit. Pada suhu tersebut, semua bakteri 
Patogen yang masih tersisa akan mati. Lalu didinginkan sehingga terbentuk produk akhir berupa pupuk cair yang murni.

\section{Mesin Pengemas Produk}

Butiran pupuk dan pupuk cair kemudian di kemas hingga menjadi produk akhir berupa pupuk padat disempurnakan yang bernama IBR.

\section{Produk Akhir}

Tabel 4 : Uji Lab Produk EATAD

\begin{tabular}{|c|c|c|c|}
\hline Jenis Pupuk & $\begin{array}{c}\text { Total } \\
\text { Nitrogen } \\
(\%)\end{array}$ & $\begin{array}{c}\text { Total } \\
\text { Phosfor } \\
(\%)\end{array}$ & $\begin{array}{c}\text { Total } \\
\text { Kalium } \\
(\%)\end{array}$ \\
\hline IBR Solid I (tanpa bahan tambahan)* & 4,1 & 1,0 & 1,5 \\
\hline IBR Solid II (+ nutrisi)* & 8,3 & 1,2 & 1,4 \\
\hline IBR Solid III (+ camp. karton \& nutrisi) ${ }^{*}$ & 8,7 & 0,7 & 0,8 \\
\hline IBR Solid IV (+ camp. karton)* & 5,4 & 1,4 & 2,0 \\
\hline 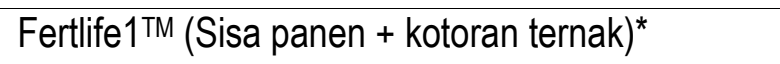 & 1,0 & 1,0 & 1,0 \\
\hline Pupuk Cacing* & 1,6 & 0,1 & 0,02 \\
\hline Garden Food $^{\mathrm{TM}}$ (sisa pemotongan hewan) ${ }^{*}$ & 5,0 & 5,2 & 5,0 \\
\hline Milorganite $^{\mathrm{TM}}$ (limbah air kotor yang di keringkan)* & 6,0 & $<0,001$ & 0,0 \\
\hline IBR Liquid I (tanpa bahan tambahan) ${ }^{* *}$ & 0,02 & 0,02 & 0,3 \\
\hline IBR Liquid II (+ nutrisi)* & 3,0 & - & 1,2 \\
\hline Beltville (limbah air kotor) ${ }^{\star *}$ & 1,0 & 0,03 & 0,2 \\
\hline Lodi (limbah air kotor) ${ }^{\star *}$ & 0,8 & & 0,4 \\
\hline Keterangan & \multicolumn{3}{|c|}{${ }^{*} \mathrm{~g} / \mathrm{kg}$ berat kering } \\
\hline & \multicolumn{3}{|c|}{${ }^{* *} \mathrm{~g} / \mathrm{kg}$ berat basah } \\
\hline
\end{tabular}

Sumber : e - Solusi.Com., PT. Biotama Recovery Indonesia (Internet, 2001), h. 6-7.

Berdasarkan penelitian di laboratorium Vancouver - Canada, sistem pengolahan sampah sistem EATAD mampu mengurangi kadar $\mathrm{BOD}_{5}$ sampai $62 \%$ dan memiliki kandungan logam berat yang dapat membahayakan bagi tanaman dalam jumlah yang sangat sedikit jika dibanding dengan pupuk produk lain. 


\section{KESIMPULAN}

- Penggunaan mikroorganisme dalam pengolahan ini diusahakan dari biakan yang terbaik.

- Penyebaran informasi kepada masyarakat bahwa sistem EATAD ini berbeda dengan sistem pengolahan yang ada sebelumnya. Juga diberitahukan kalau TPST yang menggunakan sistem ini tidak menimbun sampah, tapi hanya menerima pasokan bahan baku berupa sampah organik yang telah dipilah sebelumnya. Sehingga masyarakat, khususnya warga disekitar lokasi tidak perlu cemas akan adanya pengulangan peristiwa seperti di lokasi Bantar Gebang Bekasi.

- Melakukan uji laboratorium kembali dan disesuaikan dengan standar mutu pupuk di Indonesia, sehingga bisa membuktikan bahwa sistem EATAD ini benar-benar dapat menghasilkan produk akhir berupa pupuk dengan standar mutu yang tetap.

\section{DAFTAR PUSTAKA}

Badan Pusat Statistik Propinsi DKI Jakarta. 2004, Jakarta dalam Angka 2003. BPS,.Jakarta

Badan Pusat Statistik Propinsi DKI Jakarta. 2004.Statistik Jakarta Barat 2003. : BPS, Jakarta

Badan Pusat Statistik Propinsi DKI Jakarta. 2004.Kecamatan Cengkareng dalam Angka 2002. : BPS, Jakarta

Bahar, Yul H. 1985.Teknologi Penanganan dan Pemanfaatan Sampah. : P.T. Waca Utama Pramesti dan Pemda DKI Jakarta, Jakarta

Dardiaz, Srikandi. 1992.Mikrobiologi Pangan, : Gramedia, Jakarta

Dinas Kebersihan Propinsi DKI Jakarta._2003.Informasi Pengelolaan Kebersihan Tahun 2002. : DK, Jakarta

Dinas Pekerjaan Umum. 1998. Tutorial Pendayagunaan Aset Sarana dan Prasarana Penyehatan Pemukiman Bidang Persampahan. : DPU, Jakarta

e - Solusi.Com. 2001.P.T. Biotama Recovery Indonesia. Internet, 
Haryoto. 1998.Susu dan Yoghurt Kecipir. : Kanisius, Yogyakarta

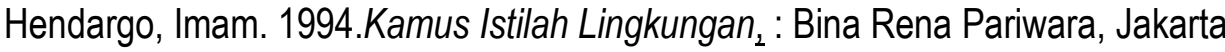

Jenie, B.S.L. dan Rahayu, W.P. 1993.Penanganan Limbah Industri Pangan. : Kanisius, Yogyakarta

Pringgodigdo, A.G. 1973. Ensiklopedi Umum.: Yayasan Kanisius, Yogyakarta

Purnomo. 1991.Pengembangan Incinerator Sampah Rumah Tangga.: Seminar IImiah Teknik Kimia Institut Teknologi Bandung, Bandung

Purwariningsih, M.W. 1996.Anggaran Perencanaan dan Pengendalian Laba edisi Indonesia. : Salemba Empat, Jakarta

Slamet, J.S. 1994. Kesehatan Lingkungan.: Gajah Mada University Press, Yogyakarta

SNI 19 - 3241 - 1994. 2004.Tata Cara Pemilihan Lokasi Tempat Pembuangan Akhir Sampah.: Badan Standarisasi Nasional, Jakarta

SNI 19 - 3242 - 1994. 2004. Sampah di Pemukiman, Tata Cara Pengelolaan. : Badan Standarisasi Nasional, Jakarta

Suharto, Ign. 1995.Bioteknologi dalam Dunia Industri. : Andi Offset, Yogyakarta

Sugiharto. 1987, Dasar-dasar Pengelolaan Air Limbah. : Universitas Indonesia Press, Jakarta 